\begin{tabular}{|c|c|c|}
\hline & $\begin{array}{l}\text { Bioeduca: Journal of Biology Education } \\
\text { http://journal.walisongo.ac.id/index.php/bioeduca } \\
\text { ISSN 2714-8009 (print), 2715-7490 (online) }\end{array}$ & BíOEDUTCA \\
\hline WALISONGO & $\begin{array}{c}\text { Volume 2, Nomor 2, Tahun } 2020 \\
\text { Hal. } 125-134\end{array}$ & \\
\hline
\end{tabular}

\title{
Pengembangan Big Book untuk Meningkatkan High Order Thinking Skill Siswa SMP
}

\author{
Aisyah Ummu Jamil ${ }^{1 *}$, Listyono ${ }^{2}$, Bunga Ihda Norra $^{3}$ \\ ${ }_{1,2,3}$ Pendidikan Biologi,Universitas Islam Negeri Walisongo Semarang \\ *Email: aisyah.ummuj@gmail.com
}

\begin{tabular}{|c|c|}
\hline Informasi Artikel & ABSTRAK \\
\hline $\begin{array}{l}\text { Submit: } 22-08-2020 \\
\text { Diterima: } 06-10-2020 \\
\text { Dipublikasikan: } 11-10-2020\end{array}$ & $\begin{array}{l}\text { Penelitian ini bertujuan untuk mendeskripsikan karakteristik } \\
\text { desain prototipe big book, menguji kelayakan big book sebagai } \\
\text { sumber belajar siswa SMP, dan menguji efektivitas big book } \\
\text { dalam kegiatan pembelajaran siswa SMP. Penelitian } \\
\text { pengembangan ini menggunakan model ADDIE. Teknik } \\
\text { sampling yang digunakan dalam penelitian ini adalah cluster } \\
\text { sample. Data diperoleh dari observasi, angket uji validitas, } \\
\text { angket tanggapan peserta didik serta hasil pretest dan posttest. } \\
\text { Hasil validasi oleh ahli materi, ahli media, guru mata pelajaran } \\
\text { dan peserta didik menunjukan bahwa media pembelajaran big } \\
\text { book ini layak digunakan dalam proses pembelajaran. } \\
\text { Penggunaan big book dinilai belum efektif dengan tingkat } \\
\text { keefektifan adalah } 40 \% \text {. Peningkatan hasil belajar juga masih } \\
\text { rendah dengan rata-rata N-gain 0,29. Hal ini dapat dipengaruhi } \\
\text { oleh beberapa faktor antara lain: kegiatan pembelajaran yang } \\
\text { kurang maksimal dalam hal ini pemilihan pendekatan } \\
\text { pembelajaran, model pembelajaran atau metode pembelajaran } \\
\text { yang kurang tepat. } \\
\text { Kata kunci: Big Book; High Order Thinking Skill; Pengembangan. }\end{array}$ \\
\hline Penerbit & ABSTRACT \\
\hline $\begin{array}{l}\text { Program Studi Pendidikan } \\
\text { Biologi, Fakultas Sains dan } \\
\text { Teknologi, UIN Walisongo } \\
\text { Semarang }\end{array}$ & $\begin{array}{l}\text { This study aims to describe the characteristics of the big book } \\
\text { prototype design, to test the feasibility of the big book as a } \\
\text { learning resource, and to test the effectiveness of the big book in } \\
\text { the learning activities of junior high school students. This } \\
\text { development research uses the ADDIE model. The sampling } \\
\text { technique used in this study was a cluster sample. Data obtained } \\
\text { from observations, questionnaires, and the results of the pretest } \\
\text { and posttest. The results of validation by content experts, media } \\
\text { experts, subject teachers and students show that the big book } \\
\text { learning media is suitable for use in the learning process. The } \\
\text { use of the big book is considered ineffective with an } \\
\text { effectiveness level of } 40 \% \text { The improvement in learning } \\
\text { outcomes is also still low with an average N-gain of 0.29. This } \\
\text { can be influenced by several factors, including: less than optimal } \\
\text { learning activities, in this case the selection of learning } \\
\text { approaches, learning models or learning methods that are not } \\
\text { quite right. } \\
\text { Keywords: Big Book; Development; High Order Thinking Skill. }\end{array}$ \\
\hline
\end{tabular}

Copyright $\mathcal{O} 2020$, Bioeduca: Journal of Biology Education 


\section{PENDAHULUAN}

Keberhasilan dalam kegiatan pembelajaran ditunjang oleh empat komponen yaitu komponen tujuan, komponen materi, komponen strategi belajar mengajar, dan komponen evaluasi (Rusman, 2013). Keberhasilan proses pembelajaran tidak tergantung pada kecanggihan suatu media, akan tetapi dari ketepatan dan keefektifan media yang digunakan oleh guru.

Media inovatif dalam pembelajaran salah satunya adalah media cetak. Salah satu contoh media cetak adalah big book. Big book dapat menjadi salah satu alternatif media pembelajaran yang digunakan dalam menunjang kegiatan pembelajaran IPA di kelas. Big book (buku besar) adalah buku bacaan yang memiliki ukuran, tulisan, dan gambar yang besar. Big book berkarakteristik khusus yang dibesarkan, baik teks maupun gambarnya, sehingga memungkinkan terjadinya kegiatan membaca bersama (Sulaiman, 2017).

Siswa sekolah menengah pertama berada pada tahap remaja awal dengan rentang usia antara 12-15 tahun. Pada usia ini, siswa berada dalam masa pubertas, dimana terjadi transisi dan perkembangan pada dirinya baik secara fisik, psikis, maupun secara sosial. Siswa mulai meninggalkan peran sebagai anak-anak dan berusaha tidak tergantung pada orang tua. Fokus dari tahap ini adalah penerimaan terhadap bentuk kondisi fisik serta berupaya mengembangkan diri melalui pergaulan dengan membentuk teman sebayanya (peer group) (Wendari, dkk., 2016).

Pengembangan Higher Order Thinking Skills (HOTS) dalam pembelajaran merupakan salah satu wujud pengimplementasian kurikulum 2013, sehingga kegiatan pembelajaran maupun evaluasi yang dilakukan hendaknya berorientasi pada HOTS. Salah satu upaya kongkrit pemerintah untuk mewujudkan hal tersebut diantaranya melalui adanya peningkatan persentase soal-soal kategori HOTS (Badjeber dan Purwaningrum, 2018).

Karakteristik skills masyarakat abad ke-21 yang dipublikasikan oleh Partnership of 21st Century Skill mengidentifikasikan bahwa pelajar pada abad ke-21 harus mampu mengembangkan keterampilan kompetitif yang diperlukan pada abad ke-21 yang berfokus pada pengembangan higher order thinking skill, seperti : berpikir kritis (critical thinking), pemecahan masalah (problem solving), keterampilan berkomunikasi (communication skills), melek TIK, tekhnologi informasi dan komunikasi (ICT, information and Communication Technology), melek informasi (information literacy), dan melek media (media literacy). Pentingnya penguasaan keterampilan berpikir tingkat tinggi terdapat dalam beberapa poin Standar Kompetensi Lulusan Sekolah Menengah. Poin yang diharapkan yaitu siswa dapat membangun dan menerapkan informasi atau pengetahuan secara logis, kritis, kreatif, dan inovatif; menunjukkan kemampuan berpikir logis, kritis, kreatif, dan inovatif dalam pengambilan keputusan; serta menunjukkan kemampuan menganalisis dan memecahkan masalah kompleks (Wahid dan Karimah, 2018).

Capaian pembelajaran peserta didik dapat diukur dengan melakukan penilaian, salah satunya penilaian pada kemampuan kognitif. Ranah kognitif merupakan kemampuan berpikir yang meliputi kemampuan intelektual yang lebih sederhana, 
kemampuan mengingat sampai pada kemampuan memecahkan masalah. Ranah kognitif dapat diukur dengan melakukan sebuah penilaian menggunakan instrumen penilaian kemampuan berpikir tingkat tinggi sesuai dengan yang diharapkan pada kurikulum 2013. Beberapa studi internasional telah dilakukan untuk mengukur kemampuan berpikir tingkat tinggi peserta didik, diantaranya Trends in International Mathematics and Science Study (TIMSS) dan Program for International Student Assessment (PISA). Indonesia adalah salah satu negara yang mengikuti studi Internasional PISA sejak tahun 1999, namun capaian peserta didik Indonesia masih dikategorikan rendah dibandingkan negara lain dan tidak mengalami peningkatan yang berarti dalam 5 periode terakhir, ini dapat disimpulkan kemampuan berpikir tingkat tinggi peserta didik masih tergolong rendah (Putri dkk, 2018).

Hasil wawancara awal dengan guru mata pelajaran IPA SMP Muhammadiyah 03 Karangpandan (Warsito, S.Pd.) peserta didik mengalami kesulitan menerima pelajaran dengan model saintifik kurikulum 2013 sehingga dalam pembelajaran guru mata pelajaran menggunakan model pembelajaran konvensional dengan papan tulis yang menyita waktu pelajaran. Peserta didik kurang dapat berperan aktif dalam kegiatan pembelajaran. Menurut Warsito, S.Pd., sumber belajar yang saat ini digunakan belum mendukung pengembangan kemampuan berpikir tingkat tinggi peserta didik. Hasil wawancara dengan lima orang peserta didik kelas VII SMP Muhammadiyah 03 Karangpandan, peserta didik merasa lebih tertarik jika pembelajaran IPA dilaksanakan di luar kelas, karena pembelajaran yang monoton akan membuat peserta didik merasa bosan. Peserta didik yang tidak tertarik dengan proses pembelajaran di dalam kelas akan memecah konsentrasi mereka dalam memahami penjelasan guru, sehingga pemahaman pada konsep materi yang disampaikan kurang dan berimplikasi terhadap pencapaian hasil belajar peserta didik. Peserta didik juga berharap terdapat media pembelajaran baru yang menarik.

Berdasarkan permasalahan tersebut diatas, dapat diketahui tujuan penelitian yaitu mendeskripsikan karakteristik desain prototipe big book untuk memberikan informasi kepada peneliti lain, menguji kelayakan big book untuk digunakan sebagai sumber belajar siswa SMP Muhammadiyah 03 Karangpandan, dan menguji efektivitas big book untuk digunakan dalam kegiatan pembelajaran siswa SMP Muhammadiyah 03 Karangpandan. Penggunaan Big Book membuat siswa lebih mudah memahami materi (Arina, dkk. 2019). Sehingga apabila siswa mudah memahami materi maka siswa juga lebih mudah dalam berpikir tingkat tinggi.

\section{METODE PENELITIAN}

Jenis penelitian ini adalah penelitian pengembangan. Penelitian dan pengembangan, Desain penelitian ini menggunakan model ADDIE (Analysis-DesignDevelop-Implement-Evaluate) menurut Branch. Tahapan atau prosedur pengembangan media pembelajaran big book pada penelitian ini digambarkan dalam bagan Gambar 1. berikut ini: 


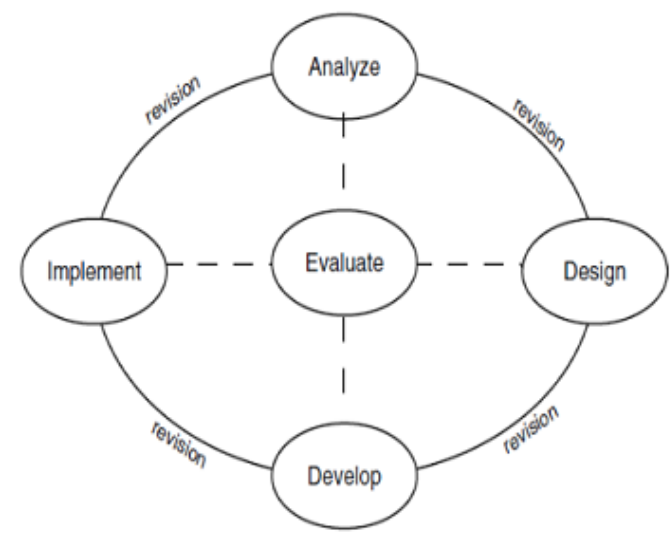

\section{Gambar 1. Model Pengembangan Development Research menurut Branch}

(Sumber: Branch, 2009)

Teknik sampling yang digunakan dalam penelitian ini adalah sampel kelompok atau cluster sample.Teknik sampel didasarkan pada kelompok peserta didik yang sudah ada. Teknik pengumpulan data dalam penelitian ini adalah observasi, wawancara, angket, tes, dan dokumentasi.

Data yang diperoleh terdiri dari data hasil pendahuluan atau observasi (wawancara guru, wawancara peserta didik dan studi literatur), angket uji ahli (validitas), angket tanggapan peserta didik dan data hasil pretest dan posttest uji kelompok besar. Data yang diperoleh dari hasil wawancara dan studi literatur diolah secara kualitatif. Data yang diperoleh dari angket dengan pertanyaan menggunakan skala Likert dan rating scale sedangkan data hasil uji kelompok besar (pretest dan posttest) dianalisis dengan menggunakan kriteria efektivitas dan uji $\mathrm{N}$-gain.

Adapun teknik analisis data yang digunakan sebagai berikut: hasil wawancara dan studi literatur dikumpulkan dan diambil kesimpulannya untuk menentukan permasalahan. Data yang dihasilkan dari angket validasi, angket tanggapan peserta didik dianalisis menggunakan rating scale (skala bertingkat). Data yang diperoleh berupa angka kemudian ditafsirkan dalam pengertian kualitatif. Skala model rating scale, responden tidak akan menjawab salah satu dari jawaban kualitatif yang telah disediakan, tetapi menjawab salah satu jawaban kuantitatif yang disediakan. Angket akan diolah dengan dua cara, yaitu menghitung persentase jawaban dari setiap item pertanyaan dan menghitung rata-rata jawaban berdasarkan skoring setiap jawaban dari responden (Sugiyono, 2010).

Rating scale dengan lima alternatif jawaban dapat dibuat angka 4 sampai 0 . Jawaban sangat baik diberi angka 4, baik diberi angka 3, cukup baik diberi angka 2, kurang baik diberi angka 1 dan sangat kurang diberi angka 0 , seperti pada Tabel 1.

Tabel 1. Kriteria rating scale

\begin{tabular}{cc}
\hline Skor & Jawaban \\
\hline 4 & Sangat Baik (SB) \\
3 & Baik (B) \\
2 & Cukup Baik (CB) \\
1 & Kurang Baik (KB) \\
0 & Sangat Kurang (SK) \\
\hline
\end{tabular}


Persentase jawaban dari setiap item pertanyaan dapat dihitung dengan menggunakan rumus:

$$
\text { Persentase }=\frac{\sum \text { skor seluruh responden }}{\sum \text { responden } \times 4} \times 100 \%
$$

(Sugiyono, 2010)

Persentase jawaban dari seluruh item pertanyaan dapat dihitung dengan menggunakan rumus:

$$
\text { Persentase }=\frac{\sum \text { skor } \text { keseluruhan } \text { kriteria responden }}{\sum \text { responden } x \sum \text { soal } x 4} \times 100 \%
$$

(Sugiyono, 2010)

Angket validasi ahli, selain menggunakan rating scale jawaban kesimpulan dari hasil validasi menggunakan skala Guttman. Skala Guttman akan menghasilkan jawaban yang tegas, yaitu "ya" atau "tidak", dalam angket ini digunakan skala "layak" atau "tidak layak".

Kesimpulan dapat ditarik dari kelayakan media dapat dicari menggunakan rumus sebagai berikut:

$$
\frac{\sum \text { jawaban layak dari responden }}{\text { Eresponden }} \times 100 \%
$$

Keterangan:

$$
\begin{array}{ll}
0-50 \% & =\text { Tidak layak } \\
51-100 \% & =\text { Layak }
\end{array}
$$

Uji efektivitas yang dilakukan oleh peneliti adalah dengan melihat seberapa banyak peserta didik yang mendapatkan hasil tes $\geq$ KKM setelah belajar menggunakan media pembelajaran big book. Kriteria efektivitas berdasarkan hasil belajar kognitif dapat dilihat pada Tabel 2 (Frasidik, 2017).

Tabel 2. Kriteria efektivitas berdasarkan hasil belajar kognitif

\begin{tabular}{cc}
\hline Persentase & Kriteria \\
\hline $80 \%$ & Sangat efektif \\
$70-79 \%$ & Efektif \\
$60-69 \%$ & Cukup Efektif \\
$50-59 \%$ & Kurang Efektif \\
$\leq 49 \%$ & Tidak Efektif \\
\hline
\end{tabular}

Analisis peningkatan hasil belajar peserta didik dapat menggunakan Uji Normal Gain. Gain adalah selisih antara nilai posttest dan pretest, gain menunjukkan peningkatan hasil belajar peserta didik setelah pembelajaran dilakukan oleh guru (Frasidik, 2017). Rumus Normal Gain menurut Meltzer yaitu:

$$
N-\text { gain }=\frac{\text { skor posttest }- \text { skor pretest }}{\text { skor ideal }- \text { skor pretest }}
$$

Adapun untuk kriteria rendah, sedang dan tinggi mengacu pada kriteria yang diungkapkan Hake, yaitu sebagaimana disajikan Tabel 3. berikut: 
Tabel 3. Kriteria $\mathbf{N}$-gain

\begin{tabular}{cc}
\hline $\mathbf{G}$ & Keterangan \\
\hline $\mathrm{g}>0,7$ & Tinggi \\
$0,3<\mathrm{g} \leq 0,7$ & Sedang \\
$\mathrm{g} \leq 0,3$ & Rendah \\
\hline
\end{tabular}

\section{HASIL PENELITIAN DAN PEMBAHASAN}

Uji lapangan dilakukan dengan melakukan penilaian pada berbagai aspek dengan tujuan untuk mengetahui tingkat kelayakan suatu produk. Proses uji lapangan tersebut dilakukan dengan menggunakan beberapa instrumen untuk menilai kelayakan big book yang dikembangkan. Kompetensi yang diharapkan setelah peserta didik belajar dengan big book adalah peningkatan kemampuan berpikir tingkat tingginya maka soal untuk pretest dan posttest divalidasi oleh dosen ahli bidang HOTS.

Data yang diperoleh dalam penelitian terdiri dari data hasil pendahuluan atau observasi, angket uji validitas, angket tanggapan peserta didik dan data hasil pretest dan posttest uji kelompok besar. Berdasarkan hasil wawancara dengan guru dan tanggapan peserta didik diperoleh data bahwa peserta didik mengalami kesulitan menerima pelajaran dengan model saintifik kurikulum 2013 sehingga dalam pembelajaran guru mata pelajaran menggunakan model pembelajaran konvensional dengan papan tulis yang menyita waktu pelajaran. Peserta didik kurang dapat berperan aktif dalam kegiatan pembelajaran. Peserta didik merasa lebih tertarik jika pembelajaran IPA dilaksanakan di luar kelas, karena pembelajaran yang monoton akan membuat peserta didik merasa bosan. Peserta didik yang tidak tertarik dengan proses pembelajaran di dalam kelas akan memecah konsentrasi mereka dalam memahami penjelasan guru, sehingga pemahaman pada konsep materi yang disampaikan kurang dan berimplikasi terhadap pencapaian hasil belajar peserta didik. Peserta didik juga berharap terdapat media pembelajaran baru yang menarik. Berdasarkan pendefinisian masalah, big book dirancang dengan menentukan tes acuan patokan, dan penentuan media. Peneliti juga membuat instrumen dan produk rancangan awal (prototipe) yang kemudian diuji pada validator, yang meliputi ahli materi, ahli media dan ahli pendidikan (Guru mata pelajaran). Grafik uji kelayakan (kevalidan) produk dapat diamati pada Gambar 2.

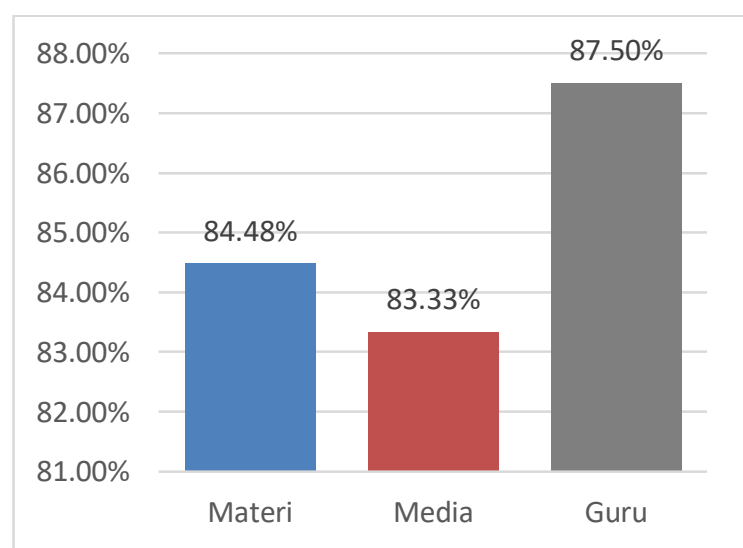

Gambar 2. Grafik Hasil Uji Kelayakan Ahli 
Hasil uji kelayakan mendapatkan penilaian dari ahli materi sebesar $84,48 \%$, dari ahli media sebesar $83,3 \%$ dan dari guru mata pelajaran sebesar $87,50 \%$. Hasil ini dapat menunjukan bahwa big book yang dikembangkan sudah masuk dalam kriteria layak dan bisa digunakan pada kegiatan pembelajaran namun dengan revisi sesuai dengan saran dan masukan ahli dan guru. Melalui penggunaan big book ini diharapkan dapat meningkatkan kualitas proses belajar mengajar yang akhirnya dapat mempengaruhi kualitas hasil belajar peserta didik. Perbaikan atau revisi pada tahap ini adalah untuk menjadikan big book lebih baik sehingga layak untuk diujikan pada tahapan selanjutnya.

Media big book merupakan media yang disenangi anak-anak dan dapat dibuat sendiri oleh guru. Big book berukuran besar ini biasanya untuk anak kelas rendah. Agar dalam proses pembelajaran, didalamnya terjadi kegiatan membaca bersama (shared reading) antara guru dan peserta didik (Novitasari, dkk., 2018). Berdasarkan hasil uji coba skala kecil dengan pemberian angket tanggapan peserta didik, media big book yang dikembangkan disenangi siswa. Uji coba skala kecil dengan melibatkan 10 orang peserta didik kelas VII yang diambil secara acak. Berdasarkan hasil tanggapan 10 orang peserta didik apabila dirata-rata big book diberi nilai sebesar $84,61 \%$ artinya big book tersebut masuk dalam kategori layak. Tahap selanjutnya setelah uji skala kecil adalah uji coba skala besar pada 30 orang peserta didik dengan melakukan uji kognitif. Uji kognitif pada penelitian ini dilakukan dengan uji pretest dan posttest untuk mengetahui efektivitas dan peningkatan hasil belajar peserta didik. Uji efektivitas yang dilakukan oleh peneliti adalah dengan melihat seberapa banyak peserta didik yang mendapatkan hasil tes $\geq \mathrm{KKM}$ setelah belajar menggunakan media pembelajaran big book. Analisis peningkatan hasil belajar peserta didik dapat menggunakan Uji Normal Gain. Berdasarkan hasil pretest dan posttest dapat dibuat grafik untuk melihat peningkatan hasil belajar. Grafik hasil pretest dan posttest dapat dilihat pada Gambar 3.

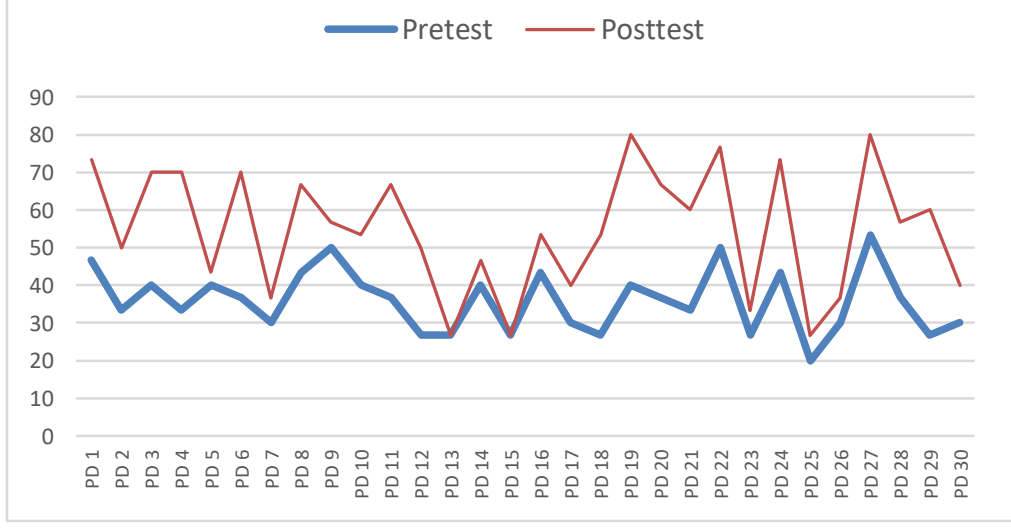

Gambar 3. Grafik hasil pretest dan posttest

Hasil pretest diperoleh sebelum diadakannya kegiatan pembelajaran dengan menggunakan big book. Rata-rata hasil uji pretest adalah 35,92 dengan nilai tertinggi 53,40 dan nilai terendah adalah 20,00. Hasil posttest diperoleh setelah peserta didik memperoleh materi dari pembelajaran dengan big book yang dilakukan bersama 
peneliti. Rata-rata hasil uji posttest adalah 54,81 dengan nilai tertinggi 80,00 dan nilai terendah adalah 26,70. Pendekatan pembelajaran yang peneliti pilih untuk pengambilan data ini adalah Contextual teaching learning dengan model pembelajaran cooperative learning dan metode pembelajaran diskusi dan tanya jawab.

Pretest dan posttest ini menggunakan 10 soal HOTS (High Order Thinking Skil) yang sama. Peserta didik mengalami peningkatan yang kurang signifikan setelah diadakannya pembelajaran dengan menggunakan big book. Hasil uji efektivitas memperoleh persentase sebesar $40 \%$ dengan melihat banyaknya peserta didik yang mendapatkan hasil tes lebih dari atau sama dengan KKM, hal ini berarti penggunaan media pembelajaran big book tidak efektif dalam meningkatkan high order thinking skillpeserta didik SMP Muhammadiyah 03 Karangpandan. Hasil uji normal gain atau uji peningkatan hasil belajar dihitung dengan rumus:

$$
\begin{gathered}
N-\text { gain }=\frac{\text { skor posttest }- \text { skor pretest }}{\text { skor ideal }- \text { skor pretest }} \\
N-\text { gain }=\frac{54,81-35,92}{100-35,92} \\
N-\text { gain }=0,29
\end{gathered}
$$

Tidak efektifnya hasil uji efektivitas dan uji $n$-gain yang rendah ini dapat dipengaruhi oleh beberapa faktor antara lain: kegiatan pembelajaran yang kurang maksimal dalam hal ini pemilihan pendekatan pembelajaran, model pembelajaran dan atau metode pembelajaran yang kurang tepat untuk pembelajaran dengan media pembelajaran big book, faktor lain dapat dipengaruhi oleh tidak cukupnya waktu pada saat pembelajaran sehingga peserta didik kurang memahami isi dalam big book. Selain itu, siswa belum terbiasa dengan soal dengan kategori HOTS, sebagaimana Hartini, dkk (2018) menyatakan bahwa hasil test yang memetakan siswa kedalam kategori HOTS rendah dikarenakan siswa tidak terbiasa mendapat soal dengan tipe C4 sampai dengan C6.

\section{SIMPULAN DAN SARAN}

Berdasarkan hasil penelitian dan pengembangan yang dilakukan peneliti, dapat diambil kesimpulan, produk hasil pengembangan berupa big book dunia binatang Avertebrata yang dikembangkan dengan metode ADDIE layak digunakan dalam pembelajaran di SMP Muhammadiyah 03 Karangpandan Kabupaten Karanganyar. Media pembelajaran big book dipilih dengan alasan bahwa buku besar ini memiliki karakteristik yang sesuai digunakan di kelas awal, dimana kelas VII merupakan peralihan dari SD ke SMP. Tingkat keefektifan peserta didik dalam pembelajaran menggunakan big book memperoleh persentase nilai $40 \%$ yang artinya kegiatan pembelajaran dengan menggunakan big book ini tidak efektif, sehingga $\mathrm{H}_{0}$ diterima. Hasil uji normal gain atau uji peningkatan hasil belajar memperoleh nilai rata-rata 0,29 yang berarti peningkatan hasil belajar peserta didik masuk kriteria rendah.

Sebagai rekomendasi bagi peneliti selanjutnya, agar penelitian yang dilakukan dapat dilakukan dengan penelitian yang berbeda dengan topik yang sama seperti 
penelitian dengan menguji efektivitas, hubungan atau pengaruh big book terhadap hasil belajar atau minat belajar. Bagi peserta didik, disarankan untuk meningkatkan kebiasaan belajar mandiri dengan cara menggunakan media pembelajaran alternatif. Big book ini dapat digunakan sebagai media pembelajaran alternatif yang bisa membantu meningkatkan pemahaman terhadap materi pelajaran IPA materi pokok klasifikasi makhluk hidup sub materi kingdom animalia. Bagi guru, hendaknya lebih meningkatkan keterampilan dalam membuat media dengan cara merancang media pembelajaran yang sesuai dengan kebutuhan peserta didik dan berkaitan dengan konsep Islam, kehidupan sehari-hari dan informasi kesehatan. Big book merupakan salah satu media alternatif yang dapat dikembangkan oleh guru sebagai media yang kreatif dan inovatif, untuk meningkatkan hasil belajar peserta didik.

\section{RUJUKAN}

Arina Restiani, dkk. (2019). "Pengembangan Media Big Book Belajar Bersama Dodo Dan Teman-Teman Untuk Pembelajaran Tematik Kelas IV Di Sekolah Dasar".Universitas Muhammadiyah Malang. p-ISSN: 2442-7470 | e-ISSN: 2579-4442. Volume 5 Nomor 2 Edisi Juli 2019. Jurnal Cakrawala Pendas

Badjeber, R. dan Purwaningrum, J.P. (2018). Pengembangan Higher Order Thinking Skills dalam Pembelajaran Matematika di SMP. Jurnal Pendidikan dan Pembelajaran 1(1): 36-43.

Branch, Maribe R. (2009). Instructional Design: The ADDIE Approach. USA: University Of Georgia dari https://books.google.co.id

Frasidik, Habsi. (2017). Pengembangan Media Pembelajaran Hypermedia untuk Meningkatkan High Order Thinking Skill pada Materi Alat Optik SMA. Skripsi. Jakarta: Program Studi Fisika Jurusan Pendidikan Ilmu Pengetahuan Alam Fakultas IImu Tarbiyah dan Keguruan UIN Syarif Hidayatullah Jakarta.

Hartini T., Misri M A., Nursuprianah, I. (2018). Pemetaan HOTS Siswa Berdasarkan Standar PISA dan TIMSS untuk Meningkatkan Mutu Pendidikan. EduMa. 6(1): 83-92

Laily, Evi K. dan Gunansyah, G. (2018). Penggunaan Media Big Book Terhadap Kemampuan Berpikir Kritis Siswa Kelas V SDN Rangkah 1 Surabaya. Jurnal PGSD Universitas Negeri Surabaya . 6(1): 1801-1810.

Novitasari, dkk. (2018). Pengaruh Media Big Book Terhadap Kemampuan Literasi Awal Anak Usia 5-6 Tahun di Kecamatan Cibalung. Jurnal JPP PAUD UNTIRTA. 5(1): 27-36.

Pamela, I.S., dkk. (2019). Penggunaan Media Big Book untuk Meningkatkan Kemampuan Berpikir Kritis Siswa di Kelas V Sekolah Dasar. Jurnal Gentala Pendidikan Dasar 4(2):245-263.

Putri, Riri R., dkk. (2018). Analisis Aspek Kemampuan Berpikir Tingkat Tinggi pada Instrumen Penilaian Materi Protista untuk Peserta Didik SMA/MA Kelas X. Jurnal Biodik.4 (1): 8-17.

Rusman. (2013). Model-Model Pembelajaran. Jakarta: PT Raja Grafindo Persada.

Sugiyono. (2010). Statistika untuk Penelitian. Bandung: Alfabeta.

Sugiyono. (2014). Metode Penelitian Kuantitatif Kualitatif dan R\&D, Bandung:Alfabeta.

Sulaiman, Umar. (2017). Pengaruh Penggunaan Media Big Book Dalam Pembelajaran Terhadap Keterampilan Literasi Siswa Kelas Awal Madrasah Ibtidaiyah Negeri Banta-Bantaeng Makassar. Jurnal al-Kalam. IX (2): 193-204. 
Wahid, A.H., dan Karimah, R.A. (2018). Integrasi Higher Order Thinking Skill (HOTS) dengan Model Creative Problem Solving. Jurnal Program Studi PGMI 5(1): 8298.

Wendari, W.N., dkk. (2016). Profil Permasalahan Siswa Sekolah Menengah Pertama (SMP) Negeri di Kota Bogor. Jurnal Bimbingan Konseling 5(1): 134-139. 